\title{
THE PRODUCTIVITY AND THE QUALITY OF GREEN MASS AND HAY FROM ROMANIAN CULTIVARS OF FESTUCA ARUNDINACEA, GROWN IN THE REPUBLIC OF MOLDOVA
}

\author{
Victor ȚT̂TEI $^{1^{*}}$, Vasile Adrian BLAJ ${ }^{2}$, Teodor MARUȘCA ${ }^{2}$ \\ 1 “Alexandru Ciubotaru” National Botanical Garden (Institute), Chişinău - Republic of Moldova \\ ${ }^{2}$ Research and Development Institute for Grasslands Braşov - România \\ *Corresponding author. E-mail: vic.titei@gmail.com; vtitei@mail.ru
}

\begin{abstract}
Grasses are considered as one of the most important sources in low-cost feed for for animals, but also a substrate for the production of renewable energy. We studied the quality of the freshly harvested biomass and hay of Romanian cultivars of tall fescue Festuca arundinacea: 'Adela', 'Brio', 'Măgurele 5', created at the Research and Development Institute for Grasslands, Braşov, Romania and cultivated in the experimental plot of the National Botanical Garden (Institute) "Alexandru Ciubotaru", Chisinau, Republic of Moldova. The samples for assessment were taken in the $2^{\text {nd }}$ year of growth, when the plants were cut for the $1^{\text {st }}$ time. The amount of dry matter (DM), crude protein (CP), crude ash (CA), neutral detergent fiber (NDF), acid detergent fiber (ADF), acid detergent lignin (ADL), cellulose (Cel), hemicellulose (HC), digestible dry matter (DDM), organic matter digestibility (OMD), relative feed value (RFV), the metabolizable energy (ME), the net energy for lactation (NEl), biomethane production potential (BMP) were analyzed. It has been determined that the green mass productivity of the tall fescue cultivars achieved 30.83-36.96 t/ha, the dry matter contained 114-136 g/kg CP, 74-89 g/kg CA, 582-593 g/kg NDF, 392-396 g/kg ADF, 34-41 g/kg ADL, 322- 329 g/kg Cel, 226-229 g/kg HC, 60.363.8\% DDM and 57.2-62.2\% OMD, 9.12-9.62 MJ/kg ME and 5.69-5.86 MJ/kg NEl; the hay dry matter contained 99-117 g/kg CP, 80-86 g/kg CA, 582-593 g/kg NDF, 356-366 g/kg ADF, 34-37 g/kg ADL, 351-356 g/kg Cel, 236-260 g/kg HC, 55.8-57.2\% DDM and 51.4-53.3\% OMD, 9.51-9.59 MJ/kg ME and 5.53-5.59 MJ/kg NEl, this fact indicates a optimal quality of the roughage feed for ruminants. The substrate for the anaerobic digestion, consisting of fresh mass of tall fescue, had a biomethane production potential of 349-354 L/kg of organic matter. The studied cultivars of tall fescue could be used in the Republic of Moldova for the restoration of degraded permanent grasslands, as a component of the mix of grasses for the creation of temporary grasslands and can be planted between rows in vineyards and orchards. Besides, the obtained biomass can be used as feed for animals or as substrate at biomethane production plants.
\end{abstract}

Keywords: biomethane production, cv. Adela, cv. Brio, cv. Măgurele 5, feed value, Festuca arundinacea, productivity.

\section{Introduction}

Grasslands are important as habitat for many plant species, including species at risk, provide soil and water conservation, nutrient recycling, pollination, habitat for livestock grazing, genetic material for crops, recreation, climate regulation, and storage for about $34 \%$ of the terrestrial global carbon stock. Grasses are considered as one of the most important sources in low-cost feed for domestic herbivores animals [COTIGĂ, 2010; MARUŞCA \& al. 2011; BAHCIVANJI \& al. 2014], but also a feedstock for the production of renewable energy [ENIRY \& O’KIELY, 2014; ROMAN \& al. 2015; KANDEL \& al. 2017].

An important component of the land resources of Romania is the area of 4.9 million hectares of permanent grasslands, considered, quite rightly, a national treasure because it represents $33 \%$ of the agricultural land, occupying, in Europe, the $5^{\text {th }}$ place, $68 \%$ of which 
are pastures and 32\% - hayfields [MARUŞCA \& al. 2014]. Permanent grassland in the Republic of Moldova constitutes $10.1 \%$ of the territory, represented by 339000 ha of pastures and 2000 ha hayfields. The productivity of natural grasslands on slopes is low and of poor quality, reaching 400-600 kg/ha of hay, and that of floodplain grasslands is higher - 2000$2600 \mathrm{~kg} / \mathrm{ha}$ of hay. Uncontrolled grazing has diminished the abundance and dominance of typical grassland species, and thus they have been replaced by adventitious, segetal, quarantine weeds and other non-fodder and poisonous species [BAHCIVANJI \& al. 2014; LAZU, 2014; LEAH, 2016]. In the vegetation of the permanent grasslands, the most common plant species with high fodder value are representatives from Poaceae and Fabaceae families.

The Plant List includes 1741 scientific plant names of species rank for the genus Festuca, Family Poaceae, of these 646 are accepted species names. Globally, the species of the genus Festuca L. are common in the floristic composition of permanent and temporary grasslands.

Tall fescue Festuca arundinacea Schreber. (syn. Lolium arundinaceum (Schreb.) Darbysh.; Schedonorus arundinaceus (Schreb.) Dumort.) is a long-lived perennial grass, native to Europe, $\mathrm{C}_{3}$ photosynthetic group, with vigorous and erect culms 60 to $200 \mathrm{~cm}$ tall. Leaves form basal tufts, blades are 20-70 cm long and 3-12 mm wide. A tuft produces 10 to 30 flowerstalks. The inflorescence is an open to narrow branched panicle 12 to $35 \mathrm{~cm}$ long. Spikelets are three to nine flowered. Lemmas are awnless to short-awned. The fruit is a caryopsis with adherent pericarp, brownish-yellow, glabrous, oblong to ellipsoid, 6-9 $\mathrm{mm}$ long, the weight of 1000 seeds 1.8-2.6 g. Tall fescue develops an extensive and robust root system which reaches up to $150 \mathrm{~cm}$ deep, is characterised by secretions that contribute to the mobilization and use of nutrients from the soil, adapts well to conditions of excess moisture as well as drought, at the same time, it develops normally on soils with $\mathrm{pH}$ 5.5-8.0, on eroded hills and slightly salty soil. Tall fescue reproduces by seed and increases vegetatively, produces new tillers from the root crown. It is perennial and is favored by the development of short stolons, thus, in periods with excess humidity, they provide the whole root system with oxygen. Tall fescue is common in wet, alluvial grasslands, and in various areas - from plains to mountains, it has medium feed value, is resistant to grazing, being an effective solution in preventing the problems related to rumen acidosis in cows [WALSH, 1995; COTIGĂ, 2010; MARUŞCA \& al. 2011]. Festuca arundinacea is among the perennial species with the highest frequency in the floristic composition of temporary grasslands, buffer strips and lawns in green spaces. This species is almost always present in the mixtures of grassland species used in Switzerland, France and the Netherlands, as well as in the scientific recommendations developed and implemented by the Research and Development Institute for Grasslands Braşov, Romania [MARUŞCA \& al. 2014].

The valorification of renewable energy is a very topical subject at global and local level, and, the production and use of phytomass to obtain different types of fuel is very promising in our region [ROMAN \& al. 2015]. The research carried out has helped us find out that the solid biofuel from the dried biomass of Festuca arundinacea has specific density of $600-660 \mathrm{~kg} / \mathrm{m} 3$, calorific value of $16.82-17.34 \mathrm{MJ} / \mathrm{kg}$ and ash content of 2.3-3.6\% [ŢÎTEI, 2015].

The aim of the current study consisted in determining the productivity of some Romanian cultivars of Festuca arundinacea grown under the conditions of the Republic of Moldova, the quality of the green mass and hay as roughage feed for ruminant animals, as well as substrate for the production of biomethane by anaerobic digestion. 


\section{Material and methods}

The Romanian cultivars of tall fescue, Festuca arundinacea: 'Adela', 'Brio', 'Măgurele 5', created at the Research-Development Institute for Grasslands Braşov, România and cultivated in the experimental plot of the National Botanical Garden (Institute) "Alexandru Ciubotaru", Chişinău, latitude 46 $58^{\prime} 25.7^{\prime \prime} \mathrm{N}$ and longitude N28 $52^{\prime} 57.8^{\prime \prime} \mathrm{E}$, served as subjects of the research.

The green mass was harvested manually. The samples were collected after cutting the plants for the $1^{\text {st }}$ time in the second growing season, in the pre-anthesis period, in 2018. The leaf/stem ratio was determined by separating the leaves from the stem, weighing them separately and establishing the ratios for these quantities (leaves/stems). The prepared hay was dried directly in the field. The dry matter content was detected by drying the samples to a constant weight at $105{ }^{\circ} \mathrm{C}$. Some assessments of the main biochemical parameters: protein, ash, acid detergent fibre (ADF), neutral detergent fibre (NDF), acid detergent lignin (ADL), digestible dry matter (DDM), organic matter digestibility (OMD) have been evaluated using the near infrared spectroscopy (NIRS) technique PERTEN DA 7200 of the Research and Development Institute for Grassland Braşov, România. The concentration of hemicellulose (HC) and cellulose $(\mathrm{Cel})$, the relative feed value (RFV), the digestible energy (DE), the metabolizable energy (ME) and the net energy for lactation (NEl) were calculated according to standard procedures.

The carbon content of the substrates was obtained from data on volatile solids, using an empirical equation reported by BADGER \& al. (1979). The biochemical biogas potential $(\mathrm{Yb})$ and the methane potential (Ym) were calculated according to the equations elaborated by DANDIKAS \& al. (2015), based on the chemical compounds - protein, acid detergent lignin (ADL) and hemicellulose (HC) indices:

biogas $\mathrm{Yb}=670+0.44 \mathrm{~PB}+0.16 \mathrm{HC}-3.02 \mathrm{ADL}$

metan $\mathrm{Ym}=370+0.21 \mathrm{~PB}+0.05 \mathrm{HC}-1.61 \mathrm{ADL}$

\section{Results and discussions}

The leaf/stem ratio essentially influences the chemical composition of the harvested phytomass to be used as feed for animals or as feedstock for biorefinery and obtaining different industrial products. The results regarding some agrobiological peculiarities of the studied cultivars of tall fescue, Festuca arundinacea, and the structure of the harvested biomass are presented in Table 1. We would like to mention that the studied cultivars of tall fescue, at the time of harvest, in the middle of May 2018, reached the height of $68.3-75.0 \mathrm{~cm}$, the plants of the cv. 'Brio' being the highest. In the tall fescue harvested biomass the leaves content was $53.9-57.1 \%$, the amount of dry matter $-23.4-25.8 \%$. The green mass productivity did not differ essentially of the cv. 'Adela' and cv. 'Brio' (36.34-36.96 t/ha) being higher in comparison with the cv. 'Măgurele 5' (30.83 t/ha). 
Table 1. Some agrobiological peculiarities and the structure of the harvested biomass of the studied cultivars of tall fescue Festuca arundinacea

\begin{tabular}{|c|c|c|c|c|c|c|c|}
\hline \multirow{2}{*}{ Cultivars } & \multirow{2}{*}{$\begin{array}{c}\text { Plant height, } \\
\text { cm }\end{array}$} & \multicolumn{2}{|c|}{ Leaf, $\mathrm{g}$} & \multicolumn{2}{|c|}{ Stem, g } & \multicolumn{2}{|c|}{ Productivity, t/ha } \\
\hline & & $\begin{array}{l}\text { green } \\
\text { mass }\end{array}$ & $\begin{array}{c}\text { dry } \\
\text { matter }\end{array}$ & $\begin{array}{l}\text { green } \\
\text { mass }\end{array}$ & $\begin{array}{c}\text { dry } \\
\text { matter }\end{array}$ & $\begin{array}{l}\text { green } \\
\text { mass }\end{array}$ & $\begin{array}{c}\text { dry } \\
\text { matter }\end{array}$ \\
\hline Adela & 73.8 & 1.63 & 0.36 & 1.71 & 0.42 & 36.34 & 8.51 \\
\hline Brio & 75.0 & 1.59 & 0.36 & 1.83 & 0.48 & 36.96 & 8.98 \\
\hline Măgurele 5 & 68.3 & 1.48 & 0.34 & 1.62 & 0.42 & 30.83 & 7.96 \\
\hline
\end{tabular}

Because feeding costs can account for over $50 \%$ of the cost of livestock production, knowing forage quality and the needs of animals can have a significant impact on profitability. Analyzing the results of the evaluation of the biochemical composition of the dry matter from the harvested mass of the studied cultivars of tall fescue, Table 2, we found that the cultivar 'Adela' was characterized by a higher content of proteins $(13.6 \%)$, as compared with the cultivar 'Brio' (11.4\%). The cultivars 'Adela' and 'Măgurele 5' did not differ essentially in the amount of ADF and NDF, cellulose and ash in the dry matter. The cultivar 'Brio' had a lower concentration of ADF, NDF, ADL, cellulose and ash, which had a positive effect on digestibility. The cultivars 'Brio' and 'Măgurele 5' had similar concentrations of hemicelluloses in the dry matter, but lower concentrations compared with the cultivar 'Adela'.

The amount of nutrients in fodder and their digestibility influence the health of animals and the amount and quality of animal products. The digestibility of dry matter and organic matter in the cultivar 'Brio' reached $63.8 \%$ and $62.0 \%$ respectively, being higher in comparison with other cultivars. We found that the cultivar 'Măgurele 5' was characterized by lower digestibility, determined, among other things, by the increased content of acid detergent lignin.

Table 2. Biochemical composition and nutritive value of the green mass of the studied cultivars of tall fescue Festuca arundinacea

\begin{tabular}{|l|c|c|c|}
\hline \multicolumn{1}{|c|}{ Indices } & Cultivar Adela & $\begin{array}{c}\text { Cultivar } \\
\text { Brio }\end{array}$ & $\begin{array}{c}\text { Cultivar } \\
\text { Măgurele 5 }\end{array}$ \\
\hline Crude protein, g/kg DM & 136 & 114 & 128 \\
Acid detergent fibre, g/kg DM & 364 & 356 & 366 \\
Neutral detergent fibre, g/kg DM & 593 & 582 & 592 \\
Acid detergent lignin, g/kg DM & 35 & 34 & 37 \\
Cellulose, g/kg DM & 329 & 322 & 329 \\
Hemicellulose, g/kg DM & 229 & 226 & 226 \\
Crude ash, g/kg DM & 89 & 74 & 89 \\
Digestible dry matter, \% & 62.2 & 63.8 & 60.3 \\
Organic matter digestibility, \% & 59.1 & 62.0 & 57.2 \\
Digestible energy, MJ/ kg & 11.46 & 11.75 & 11.09 \\
Metabolizable energy, MJ/ kg & 9.37 & 9.62 & 9.12 \\
Net energy for lactation, MJ/kg & 5.86 & 6.02 & 5.69 \\
Relative feed value & 95 & 98 & 95 \\
Potential crude protein, kg/ha & 1157 & 1024 & 1020 \\
Potential metabolizable energy, GJ/ ha & 79.74 & 86.39 & 72.60 \\
\hline
\end{tabular}


Victor ȚîȚEI \& al.

The relative feed value (RFV) is an index that characterizes the quality of the feed by the potential capacity of the animals' body to assimilate the digestible dry matter from the feed. The studied cultivars of tall fescue had a relative feed value of 95-98 points, being of moderate to high quality in comparison with alfalfa. The experimental data indicated above reveal that the metabolizable energy of the tall fescue feed was 9.12-9.67 MJ/kg, and the net energy for lactation reached 5.69-6.02 MJ/kg. The highest potential for accumulation of crude protein was found in the cultivar 'Adela' $(1157 \mathrm{~kg} / \mathrm{ha})$ and the highest metabolizable energy - in the cultivar 'Brio' (86.39 GJ/ha).

Hay is a very popular form of preserved fodder and valuable feed for farm animals, a rich source of protein, vitamins and minerals, both in winter and throughout the year, especially for the young animals, pregnant females and breeding males. Feeding high quality hay can also reduce the level of grain supplementation needed during winter. To most livestock farmers, crude protein (CP) and relative feed values (RFV) are the basis on how much hay to buy or feed livestock [ANGIMA \& KALLENBACH, 2008]. The quality of the hay prepared from studied cultivars of tall fescue Festuca arundinacea, are presented in Table 3. The prepared hay prepared contained $99-117 \mathrm{~g} / \mathrm{kg} \mathrm{CP}, 80-86 \mathrm{~g} / \mathrm{kg} \mathrm{CA}, 582-593 \mathrm{~g} / \mathrm{kg}$ NDF, 356-366 g/kg ADF, 34-37 g/kg ADL, 351-356 g/kg Cel, 236-260 g/kg HC, 55.8-57.2\% DDM and 51.4-53.3\% OMD, 9.51-9.59 MJ/kg ME and 5.53-5.59 MJ/kg NEl Thus, the preparation of the hay resulted in a decrease in the content of crude protein and an essential increase in the content of structural carbohydrates as compared with the freshly harvested mass, and fact had a negative impact on the net energy for lactation and relative feed values.

Table 3. Biochemical composition and nutritive value of the hay prepared from of the studied cultivars of tall fescue, Festuca arundinacea

\begin{tabular}{|l|c|c|c|}
\hline \multicolumn{1}{|c|}{ Indices } & Cultivar Adela & $\begin{array}{c}\text { Cultivar } \\
\text { Brio }\end{array}$ & $\begin{array}{c}\text { Cultivar } \\
\text { Măgurele 5 }\end{array}$ \\
\hline Crude protein, g/kg DM & 117 & 99 & 108 \\
Acid detergent fibre, g/kg DM & 392 & 386 & 392 \\
Neutral detergent fibre, g/kg DM & 638 & 646 & 628 \\
Acid detergent lignin, g/kg DM & 36 & 34 & 41 \\
Cellulose, g/kg DM & 356 & 352 & 351 \\
Hemicellulose, g/kg DM & 246 & 260 & 236 \\
Crude ash, g/kg DM & 86 & 99 & 108 \\
Digestible dry matter, \% & 57.2 & 56.3 & 55.8 \\
Organic matter digestibility, \% & 52.0 & 53.3 & 51.4 \\
Digestible energy, MJ/ kg & 11.59 & 11.66 & 11.59 \\
Metabolizable energy, MJ/ kg & 9.51 & 9.59 & 9.51 \\
Net energy for lactation, MJ/ kg & 5.53 & 5.59 & 5.53 \\
Relative feed value & 85 & 87 & 86 \\
\hline
\end{tabular}

Different results regarding the biochemical composition and the nutritive value of the green mass and hay from Festuca arundinacea are given in the specialized literature. Thus, the research conducted in Argentina by SCHENEITER \& al. (2014), revealed that, depending on the harvest time, the yield increased from 0.64 to $2.82 \mathrm{t} / \mathrm{ha} \mathrm{DM}$, the NDF content increased from 503 to $604 \mathrm{~g} / \mathrm{kg}$ and the digestibility decreased from 684 to $558 \mathrm{~g} / \mathrm{kg}$. FLORES \& al. (2017), mentioned that, in the USA, tall fescue contained 56.5-67.8\% NDF, 27.7-34.9\% ADF, 28.8-34.0\% hemicellulose, 25.0-28.1\% cellulose, 3.61-10.05\% lignin. ENIRY \& O'KIELY (2014), mentioned that, in Ireland, the biomass of Festuca arundinacea, 
harvested on 12 May, contained $15.2 \%$ protein, $8.6 \%$ ash, 52.9\% NDF, 26.7\% ADF, $16.1 \%$ soluble carbohydrates, and the biomass harvested on 9 June contained $11.2 \%$ protein, $9.0 \%$ ash, $62.3 \%$ NDF, $37.2 \%$ ADF, 9.2\% soluble carbohydrates. POCIENE் \& KADŽIULIENE (2016), found that the biomass of tall fescue, depending on the amount and type of applied fertilizers, contained $14-20 \%$ hemicellulose, $34-36 \%$ cellulose and 6-9\% lignin. In Turkey the hay yield in pure Festuca arundinacea stands varied from 3.7 to 11.6 t/ha and concentration of crude protein from 10.0 to $10.9 \%$ depending on the dose nitrogen fertiliser (KOC \& al. 2004), in USA hay prepared from tall fescue cv. Kentucky 31 contained 6.377.85\% crude protein with RFV 96-98 [ANGIMA \& KALLENBACH, 2008].

Table 4. Chemical composition and biomethane production potential of green mass substrates from the studied cultivars of tall fescue, Festuca arundinacea

\begin{tabular}{|l|c|c|c|}
\hline \multicolumn{1}{|c|}{ Indices } & Cultivar Adela & $\begin{array}{c}\text { Cultivar } \\
\text { Brio }\end{array}$ & $\begin{array}{c}\text { Cultivar } \\
\text { Măgurele 5 }\end{array}$ \\
\hline Crude protein, g/kg DM & 136 & 114 & 128 \\
Minerals, g/kg DM & 89 & 74 & 89 \\
Carbon, g/kg DM & 506.1 & 514.4 & 506.1 \\
Nitrogen, g/kg DM & 21.8 & 18.2 & 20.5 \\
Carbon/nitrogen ratio & 23 & 28 & 25 \\
Acid detergent lignin, g/kg DM & 35 & 34 & 37 \\
Hemicellulose, g/kg DM & 229 & 226 & 226 \\
Biogas potential, L/kg VS & 661 & 654 & 651 \\
Biomethane potential, L/kg VS & 354 & 351 & 349 \\
Methane productivity, m/ha & 3013 & 3152 & 2778 \\
\hline
\end{tabular}

The biomass is converted into biogas by anaerobic digestion in special devices, called anaerobic digesters, by a wide variety of microorganisms, and this process results in fuel gas, which consists of methane and carbon dioxide, and digestate, which is rich in macroand micronutrients and can be used as fertilizer in organic farming. The carbon nitrogen ratio $(\mathrm{C} / \mathrm{N})$ of biomass plays a crucial role in the process of decomposition of organic matter by microorganisms. DOBRE \& al. (2014) mentioned that the optimal $\mathrm{C} / \mathrm{N}$ ratio was expected to be in the range 15-25, when the anaerobic digestion process was carried out in a single stage and for the situation when the process developed in two steps, the optimal $\mathrm{C} / \mathrm{N}$ ratio ranged between 10-45 for step I and 20-30 for step II. The results regarding the quality of the substrate and the potential for obtaining biogas and biomethane from the freshly harvested mass of the studied cultivars are shown in Table 4. We found that the substrate of Festuca arundinacea, according to the $\mathrm{C} / \mathrm{N}$ ratio, which constituted 23-28, the amount of acid detergent lignin (34-37 g/kg) and hemicellulose (226-229 g/ $/ \mathrm{gg})$ met the established standards. No essential differences were observed between the studied cultivars, in the potential for biogas (651-661 1/kg organic matter) and biomethane production (349-354 1/kg organic matter). Methane productivity ranged from 2778 to $3152 \mathrm{~m}^{3} / \mathrm{ha}$. The cultivars 'Brio' and 'Adela' were characterised by higher indices due to a higher yield of biomass. KANDEL \& al. (2017), indicated a potential methane productivity of tall fescue biomass, from the 1st harvest, of 401-428 1/kg and an annual productivity, from three harvests per growing season, of $6871 \mathrm{~m}^{3} / \mathrm{ha}$, in Denmark. ENIRY \& O'KIELY (2014), mentioned that the potential methane productivity of tall fescue biomass was $216-2681 / \mathrm{kg}$, varying depending on the harvest time. 
Tall fescue, Festuca arundinacea, is a perennial grass with economic and social interest, and the Romanian cultivars 'Brio' and 'Adela' can be used in the Republic of Moldova to restore degraded permanent grasslands, as a component of the mixtures of plants sown to create temporary grasslands, grass strips in vineyards and orchards, and the harvested biomass can be used as fodder for animals and as substrate for the production of biomethane in anaerobic digesters.

\section{Notes on contributors}

Victor ȚITTEI - is Head of the Plant Resources Laboratory "Alexandru Ciubotaru” National Botanical Garden (Institute), Chişinău, Republic of Moldova, with a PhD in Biology - Plant Physiology and Applied Botany with a special interest in the mobilization plant genetic resources, breed new cultivars and exploit their potential as forage, honey and energy crops, identification promising plant species for valorification marginal and degraded lands.

Vasile Adrian BLAJ - is General Manager of the Research and Development Institute for Grasslands Braşov, România, with a PhD in Agronomy with a special interest in grassland improvement by fertilization, fining, sowing, replanting, weed control; use of meadows, pastures for grazing, animal behavior, yield in animal production.

Teodor MARUȘCA - is titular member of the Academy of Agricultural and Forestry Sciences "Gheorghe Ionescu-Şişeşti", Head of the Laboratory plant genetic resources and breeding fodder plant of the Research and Development Institute for Grasslands Braşov, România, PhD in Agronomy with a special interest in botany, geobotany, grassland typology; mountain ecological gradient; environmental protection and biotechnical means for combating erosion, introduction of genetic resources, study and testing of perennial grass varieties; grassland improvement by fertilization, fining, sowing, replanting, weed control; use of meadows, pastures for grazing, animal behavior, yield in animal production.

\section{References}

ANGIMA S. D. \& KALLENBACH R. L. 2008. Relative feed value and crude protein of selected cool and warm season forages in response to varying rates of nitrogen. Journal of the NACAA. https://www.nacaa.com , journal > angima-PAPER

BADGER C. M., BOGUE M. J. \& STEWART D. J. 1979. Biogas production from crops and organic wastes. New Zeland Journal of Science. 22: 11-20.

BAHCIVANJI M., COŞMAN S., CARAUŞ S. \& COŞMAN V. 2012. Caracteristica şi valorificarea raţională a plantelor furajere naturale şi cultivate [in Romanian]. Chişinău, Ştiinţa. 378 pp.

COTIGĂ C. 2010. Cultura plantelor furajere. Craiova, Sitechi. 261 pp.

DANDIKAS V., HEUWINKEL H., LICHTI F., DREWES J. E. \& KOCH K. 2015. Correlation between biogas yield and chemical composition of grassland plant species. Energy Fuels. 29(11): 7221-7229.

DOBRE P., FARCAŞ N. \& MATEI F. 2014. Main factors affecting biogas production - an overview. Romanian Biotechnological Letters. 19(3): 9283-9286.

FLORES R., COBLENTZ W. K., OGDEN R. K., COFFEY K. P., LOOPER M. L., WEST C. P. \& ROSENKRANS C. F. Jr. 2007. Effects of fescue type and sampling date on the ruminal disappearance kinetics of autumnstockpiled tall fescue. Journal of Dairy Science. 90(6): 2883-2896.

KANDEL T. P., WARD A. J., ELSGAARD L., MØLLER H. B. \& LÆRKE P. E. 2017. Methane yield from anaerobic digestion of festulolium and tall fescue cultivated on a fen peatland under different harvest managements. Acta Agriculturae Scandinavica, Section B. Soil \& Plant Science. https://doi.org/ 10.1080/09064710.2017.1326522

KOC A., GOKKUS A., TAN M., COMAKLI B. \& SERIN Y. 2004. Performance of tall fescue and lucerne-tall fescue mixtures in highlands of Turkey. New Zealand Journal of Agricultural Research. 47: 61-65.

LEAH T. 2016. Grasslands of Moldova: quality status, vulnerability to anthropogenic factors and adaptation measures. Scientific Papers. Series A. Agronomy. 59: 100-105.

MARUŞCA T., TOD M., SILISTRU D., DRAGOMIR N. \& SCHITEA M. 2011. Principalele soiuri de graminee şi leguminoase perene de pajişti [in Romanian]. Braşov. Capolavoro, 52 pp. 
MARUŞCA T., MOCANU V., HAŞ E. C., TOD M.A., ANDREOIU A. C., DRAGOŞ M. M., BLAJ V. A., ENE T. A., SILISTRU D., ICHIM E., ZEVEDEI P. M., CONSTANTINESCU C. S. \& TOD S. V. 2014. Ghid de intocmire a amenajamentelor pastorale [in Romanian]. Braşov. Capolavoro. $250 \mathrm{pp}$.

MCENIRY J. \& O'KIELY P. 2014. Methane production by anaerobic digestion of tall fescue samples pre- and postensiling, prepared by thermal or freeze drying. Agricultural Engineering International: CIGR Journal. 16(1): 133-142.

POCIENÉ L. \& KADŽIULIENĖ Z. 2016. Biomass yield and fibre components in reed canary grass and tall fescue grown as feedstock for combustion. Zemdirbyste-Agriculture. 103(3): 297-304.

ROMAN G. V., ION V., EPURE L. I. \& BĂŞĂ A. G. 2016. Biomasa-sursă alternativă de energie [in Romanian]. București: Edit. Universitară, 432 pp.

SCHENEITER J. O., CAMARASA J., CARRETE J. R. \& AMENDOLA C. 2016. Is the nutritive value of tall fescue (Festuca arundinacea Schreb.) related to the accumulated forage mass? Grass and Forage Science. 71(1): 102-111.

ȚITTEI V. 2015. Promising perennial plant species for bioenergy production in the Republic of Moldova. Journal of Botany (Chisinau). 2(11): 127-131.

WALSH R. A. 1995. Schedonorus arundinaceus. In: Fire Effects Information System, [Online]. U.S. Department of Agriculture, Forest Service, Rocky Mountain Research Station, Fire Sciences Laboratory (Producer). www.fs.fed.us/database/feis/plants/graminoid/scharu/all.html

How to cite this article:

ȚITTEI V., BLAJ V. A. \& MARUȘCA T. 2019. The productivity and the quality of green mass and hay from romanian cultivars of Festuca arundinacea, grown in the Republic of Moldova. J. Plant Develop. 26: 189-196. https://doi.org/10.33628/jpd.2019.26.1.189 